\title{
Hypokalemic Periodic Paralysis Case Accompanied with Cardiac Arrhythmia
}

\author{
Kardiyak Aritminin Eşlik Ettiği Hipokalemik Periyodik Paralizi Olgusu
}

Yusuf Kenan Tekin', Gülaçan Tekin²

'Department of Emergency Medicine, Yozgat State Hospital, Yozgat, Turkey

2Department of Cardiology, Faculty of Medicine, Bozok University, Yozgat, Turkey

\section{ABSTRACT}

Introduction: Hypokalemic periodic paralysis (HPP) is a disease characterized by intermittent attacks of muscle weakness occurring at irregular intervals and accompanied by episodic hypokalemia. The most common cause of HPP is familial periodic paralysis, which is an autosomal dominantly inherited congenital disease. The serum potassium level is low during the attack due to the shift of potassium into muscle cells, but it is normal between attacks. Attacks of muscle weakness may be triggered or enhanced by high carbohydrate food consumption, emotional stress, cold, resting after strenuous exercise, drugs (such as glucocorticosteroids), insulin and diuretics, preceding infections, and pregnancy.

Case Report: We hereby present a 31-year-old male patient admitted to emergency services who had suddenly developed muscle weakness in his upper and lower extremities. Hypopotassemia was observed on the blood test, the electrocardiography was a Mobitz type I atrioventricular block, and the patient was diagnosed with familial periodic paralysis (PP).

Conclusion: Familial HPP is diagnosed if there are recurrent attacks of paralysis that are reversible with potassium replacement and hypopotassemia, without any apparent cause of hypopotassemia.

Keywords: Hypokalemia, periodic paralysis, arrhythmia

Received: 11.05.2012 Accepted: 14.11.2012

\section{ÖZET}

Giriş: Hipokalemik periyodik paralizi (HPP) düzensiz aralıklarla seyreden kas güçsüzlüğü atakları ile karakterize, hipokalemi atakIarının eşlik ettiği bir hastalıktır. HPP'nin en sık sebebi otozomal dominant geçişli konjenital bir hastalık olan ailesel periyodik paralizidir. Potasyumun kas hücresi içerisine geçişi nedeniyle atak sırasında serum potasyum düzeyi düşük fakat ataklar arasında normaldir. Kas güçsüzlüğü atakları fazla karbonhidratlı gıda tüketimi, emosyonel stres, soğuk, ağır egzersiz sonrası istirahatte, glikokortikoidler, insülin ve diüretik gibi ilaç kullanımı, geçirilmiş enfeksiyonlar ve gebelik gibi etkenler ile tetiklenebilir veya şiddetlenebilir.

Olgu Sunumu: Burada üst ve alt ekstremitelerde ani başlangıçlı kas güçsüzlüğü ile acil servise başvuran 31 yaşında erkek hasta sunduk. Ailesel PP tanısı konulan hastanın kan tetkikleride hipopotasemi ve elektrokardiyografide mobitz tip I atriyoventriküler blok saptandı.

Sonuç: Potasyum replasmanı ile düzelen paralizi ataklarının tekrarlaması, hipopotasemi ve hipopotasemiyi açıklayacak sebep olmadığında ailesel HPP tanısı konulur.

Anahtar Kelimeler: Hipokalemi, periyodik paralizi, aritmi

Geliş Tarihi: 11.05.2012 Kabul Tarihi: 14.11.2012

\section{Giriş}

Periyodik paralizi (PP) otozomal dominant geçiş gösteren, klinikte periyodik kas güçsüzlüğü veya paralizi atakları ile karakterize konjenital bir hastalıktır. Hipokalemik, hiperkalemik ve normokalemik olmak üzere üç formu vardır. Hipokalemik periyodik paralizi (HPP) en sık görülen şeklidir. Atak sırasında hipopotasemi tespit edilirken, ataklar arasında genellikle potasyum değerleri normaldir. Genellikle atakların oluşmasını tetikleyen fazla karbonhidratlı gıda tüketimi, emosyonel stres, soğuk, ağır egzersiz sonrası istirahatte, glikokortikoidler, insülin ve diüretik gibi ilaç kullanımı, geçirilmiş enfeksiyonlar ve gebelik gibi presipitan faktörler vardır. Vücutta potasyum eksikliği yoktur, potasyumun kandan kas içine geçişi artmış̧ır. HPP'de klinik bulgular aralıklı kas 
güçsüzlüğünden paraliziye kadar, sıklığı ise günden yıla kadar değişkenlik gösterebilir (1-3). Burada, kas güçsüzlüğü ile acil servise başvuran, biyokimyasal tetkiklerde hipopotasemi ve elektrokardiyografide Mobitz tip I atriyoventriküler blok saptanan ailesel HPP'li 31 yaşında erkek hasta literatür eşliğinde sunulmuştur.

\section{Olgu Sunumu}

Bilinen herhangi bir hastalığı olmayan 31 yaşında erkek hasta, her iki kol ve bacakta güçsüzlük ve yürüyememe şikayeti ile acil servise başvurdu. Acil servise gelmeden yaklaşık iki saat önce sabah uykudan uyanınca her iki bacağını hareket ettiremediğini ve kollarında da güçsüzlük olduğunu farketmiş. Tansiyon arteyal 110/70 mmHg ve nabız 76/dakika idi. Travma öyküsü olmayan hastanın, yapılan motor ve duyu muayenesinde üst ekstremitede $4 / 5$, alt ekstremitede $3 / 5$ güç kaybı olmasına rağmen duyu muayenesi normaldi. Derin tendon refleksleri azalmıştı. Akut serebrovasküler ve spinal kanal patolojilerini ekarte etmek için bilgisayarlı beyin tomografi, servikal ve lomber manyetik rezonans tetkikleri yapıldı ve sonuçlar normal olarak değerlendirildi. Daha önce benzer şikayetlerle hastaneye başvurmamış fakat ayrıntılı sorgulandığında yaklaşık 3 yıldır ara ara ellerinde ve ayaklarında uyuşma olduğunu ve kendiliğinden geçtiğini ifade etti. Ailede benzer yakınmaları olan yoktu. Kronik herhangi bir hastalığı ve ilaç kullanım öyküsü yoktu. Hastanın başvuru anında sodyum $143 \mathrm{mmol} / \mathrm{L}$, potasyum 2,5 mmol/L, kalsiyum 9,2 mmol/L, klor $112 \mathrm{mmol} / \mathrm{L}$ idi. Kreatin kinaz 665 U/L (30-200 U/L referans aralığı) idi. Kan gazı değerleri pH: 7,45, pCO2: 41,7, pO2: 46,8, Bikarbonat (HCO3): 28,4 idi. Tiroid stimülan hormon (TSH): 1,64 $\mu \mathrm{lU} / \mathrm{mL}(0,4-4 \mu \mathrm{lU} / \mathrm{mL}$ referans aralığı), serbest T3: 3,46 pg/mL (1,8-4,2 pg/mL referans aralığı), serbest T4: 1,58 ng/dL (0,8-1,9 ng/dL referans aralığı). Hastanın kusması ve gastroenteriti yoktu. Yapılan idrar tetkiklerinde özellik yoktu. Elektrokardiyografide Mobitz tip I atrioventriküler blok tespit edildi (Resim 1). Hastaya potasyum klorür infüzyonu (saatte $5 \mathrm{mEq}$ ) yapıldıktan 8 saat sonra paralizi tamamen düzeldi. Kontrol potasyum değeri 3,6 mmol/L idi. Çekilen kontrol elektrokardiyografide normal sinüs ritmi izlendi, blok izlenmedi (Resim 2). Nöroloji kliniği tarafından yatış verilerek tetkik edilen hastada hipopotasemi kliniğini açıklayacak patolojik bulguya rastlanmadı. Yedi günlük yatışın ardından hasta şifa ile taburcu oldu.

\section{Tartışma}

Periyodik paralizitler sodyum ( $\mathrm{Na}$ ), potasyum (K) veya kalsiyum (Ca) kanallarındaki mutasyonlara bağlı olarak gelişebilir (CACNA1S ve SCN4A genleri) (4-6). Herediter geçiş gösteren bu hastalıkta, reversible, simetrik tutulum gösteren tekrarlayan kas güçsüzlüğü ön plandadır. Klinikte hipokalemi, normokalemi yada hiperkalemi saptanabilir fakat hipokalemi saptanması daha sıktır (1, 3). Çoğu vakada ailesel özellik gösterirken, tirotoksik periyodik paralizi, baryum zehirlenmesi, renel tübüler asidoz, primer hiperaldosteronizm, meyan otu-kökü zehirlenmesi ve gastrointestinal kayıplara bağlı gelişen sporadik vakalar da vardır (7). Ailesel tip HPP batı ülkelerinde daha sık görülürken, tirotoksik PP'ler daha çok Asya toplumlarında ve fazla görülmektedir (4). Hastalık genellikle birinci ve ikinci dekatta bulgu vermekle birlikte daha ileri yaşlarda da görülebilir. Hastalığın şiddeti atakların sıklığına ve süresine bağlıdır (8). Hastamızda ailesel özellik saptanmadı fakat kas tutulumu simetrikti, biyokimyasal tetkiklerde hipopotasemi saptandı ve hipopotasemiyi açıklayacak patoloji saptanmadı.

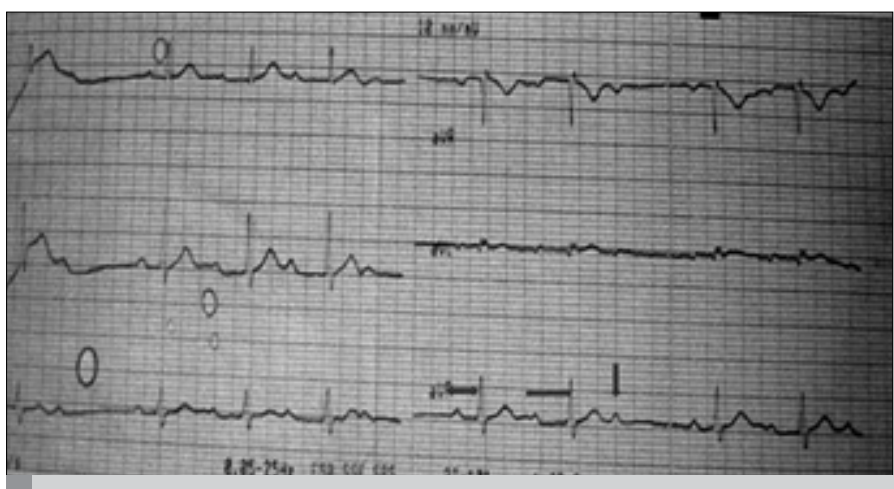

Resim 1. Elektrokardiyografide Mobitz tip I atriyoventriküler blok izlendi. P-R mesafesi sabit değildir (yatay oklar), giderek uzamakta ve cevapsız p dalgası görülmektedir (dikey ok)

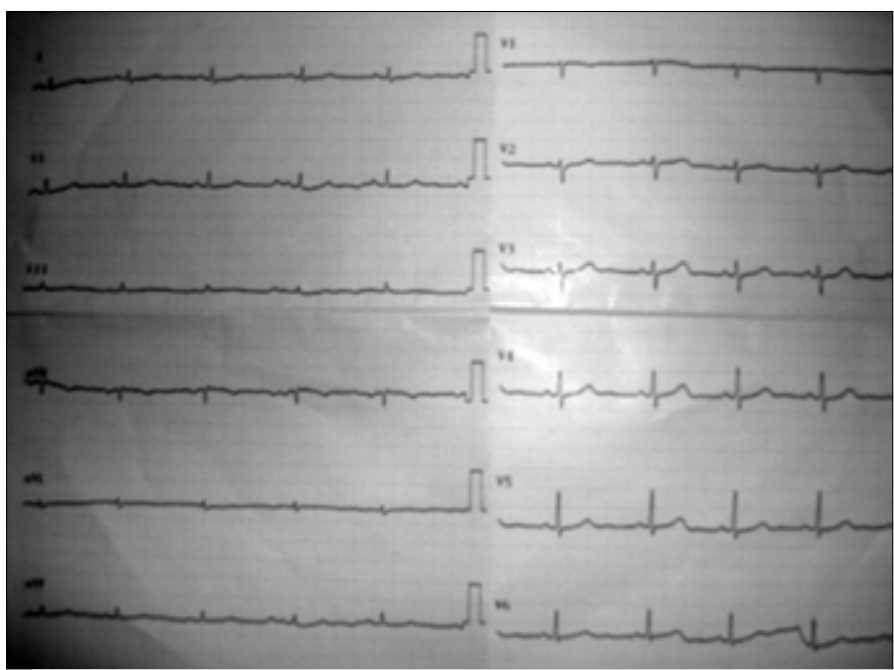

Resim 2. Hastanın potasyum değeri normale geldikten sonra çekilen elektrokardiyografide normal sinüs ritmi izlendi. Kardiyak aritmi izlenmedi

Hipokalemik periyodik paralizi kas güçsüzlüğü ve hipokalemi ile seyreden oldukça heterojen bir hastalıktır. Tanı konulamayan hastalarda solunum yetmezliğine ve ölüme kadar gidebilen kötü sonuçları olabilen tedavi edilebilir bir durumdur. Yaklaşım nedene yönelik tedavi ve potasyum replasmanından oluşmaktadır. Hastalığın seyri, şikayetlerin şiddetine, hipopotaseminin derecesine ve hastalığın kronikliğine bağlıdır $(4,7,9)$.

Hipertiroidiye sekonder gelişen hipopotasemilerde ise artmış katekolamin deşarjına sekonder olarak Na/K ATP az aktivitesindeki artışa bağlı olarak Kıın hücre içine akışı ve sonrasında gelişen paralizi tablosu görülür $(3,4)$. Ailesel geçiş gösteren HPP'lerde temel tedavi potasyum replasmanıdır ve potasyum replasmanı sonrası klinik düzelmenin hızlı olduğu görülür. Tirotoksikoza bağlı gelişen PP'lerde ise temel tedavi non selektif beta blokerler ve tercihen propranololdür. Tirotoksik PP'de potasyum replasmanı yapıldığında dirençli reaktif hiperpotasemi gelişebilir $(4,7,9)$. Bu nedenle tedaviye başlamadan önce hipopotasemi sebebinin belirlenmesi önemlidir. Hasta- 
mızda hipertiroidi kliniği yoktu ve tiroid fonksiyon testleri normaldi. Potasyum infüzyonu ile hem klinik olarak paralizi düzeldi hemde elektrokardiyografik olarak atriyoventriküler blok normal sinüs ritmine döndü. Tedaviye cevabın hızı olması ailesel HPP'yi desteklemektedir.

Hipokalemik periyodik paralizinde özellikle potasyum değerleri çok düştüğünde hayatı tehdit eden kardiyak aritmiler görülebilir. Hipopotasemiye bağlı olarak elektrokardiyografide U dalgaları, ST segment depresyonu, QT uzaması, T dalgasında düzleşme, sino-atrial bloklar ve aritmiler gelişebilir (10). Özellikle tirotoksik PP'de tedavide potasyum verildiğinde reaktif olarak gelişen dirençli hiperpotasemi de kardiyak aritmiye neden olabilir. Ayrıca TPP'de kullanılan propranolol da atriyoventriküler bloklara sebep olabilir. Atriyoventriküler blok gelişen hastalarda gerekirse geçici pace maker takılabilir (4). Hastamızda potasyum tedavisi ile hem kas güçsüzlüğü hemde kardiyak aritmide hızlı düzelme gözlendi ve reaktif hiperpotasemi gelişmedi.

\section{Sonuç}

Ekstremitelerde kas güçsüzlüğü şikayetleri ile polikliniğe veya acil servise başvuran, özellikle genç hastalarda, HPP tanısı da akla gelmeli ve hasta bu yönüyle tetkik edilmelidir. Bu tür hastalar genellikle serebrovasküler hastalıklar yönünden değerlendirilmekte ve özellikle ilk başvurularda elektrolit bozuklukları dikkatten kaçmaktadır. Ayrıca tedavide hipopotasemi nedeni tespit edildikten sonra tedavi başlanmalıdır. Hem hipopotasemide ve hem de tedaviye bağlı gelişen reaktif dirençli hiperpotasemide oluşabilecek kardiyak aritmiler yönünden dikkatli olunması gerekmektedir.

Conflict of Interest: No conflict of interest was declared by the authors.

Peer-review: Externally peer-reviewed.

Informed Consent: Written informed consent was obtained from patients who participated in this case.

Author Contributions: Concept - Y.K.T.; Design - Y.K.T.; Supervision Y.K.T., G.T.; Funding - Y.K.T.; Materials - Y.K.T., G.T.; Data Collection and/ or Processing - Y.K.T., G.T.; Analysis and/or Interpretation - Y.K.T., G.T.; Literature Review - Y.K.T., G.T.; Writer - Y.K.T.; Critical Review - Y.K.T.
Financial Disclosure: The authors declared that this study has received no financial support.

Çıkar Çatışması: Yazarlar çıkar çatışması bildirmemişlerdir.

Hakem değerlendirmesi: Dış bağımsız.

Hasta Onamı: Yazılı hasta onamı bu olguya katılan hastalardan alınmıştır.

Yazar Katkıları: Fikir - Y.K.T.; Tasarım - Y.K.T.; Denetleme - Y.K.Y.T, G.T.; Kaynaklar - Y.K.T.; Malzemeler - Y.K.T.; Veri toplanması ve/veya işlemesi - Y.K.T., G.T.; Analiz ve/veya yorum - Y.K.T., G.T.; Literatür taraması Y.K.T., G.T.; Yazıyı yazan - Y.K.T.; Eleştirel İnceleme - Y.K.T., G.T.

Finansal Destek: Yazarlar bu çalışma için finansal destek almadıklarını beyan etmişlerdir.

\section{References}

1. Finsterer J. Primary periodic paralyses. Acta Neurol Scand 2008; 117: 145-58. [CrossRef]

2. Koç F, Bozdemir H, Sarıca Y. Familyal periodik paralizili bir aile. Gülhane Tıp Dergisi 2003; 45: 379-82.

3. Dikici S, Kocaman G, Şen Ş, Ercan N. Periyodik paralizi: Olgu sunumu. Düzce Üniversitesi Sağlık Bilimleri Enstitüsü Dergisi 2011; 1: 21-3.

4. Wang HF, Tsai SC, Pan MS, Shiao CC. Complete heart block during potassium therapy in thyrotoxic periodic paralysis. J Emerg Med 2013; 44 61-4. [CrossRef]

5. Lin SH, Yang SS, Chau T. A practical approach to genetic hypokalemia. Electrolyte Blood Press 2010; 8: 38-50. [CrossRef]

6. Ebus S, Verrips A, Ginjaar IB, Verhagen WI. Gastro-enteritis in hypokalemic periodic paralysis: A life threatening condition. Clin Neurol Neurosurg 2012; 114: 801-2. [CrossRef]

7. Stedwell RE, Allen KM, Binder LS. Hypokalemic paralyses: a review of the etiologies, pathophysiology, presentation, and therapy. Am J Emerg Med 1992; 10: 143-8. [CrossRef]

8. Kim H, Hwang H, Cheong HI, Park HW. Hypokalemic periodic paralysis; two different genes responsible for similar clinical manifestations. Korean J Pediatr 2011; 54: 473-6. [CrossRef]

9. Lin SH, Lin YF, Halperin ML. Hypokalaemia and paralysis. QJM 2001; 94: 133-9. [CrossRef]

10. Alfonzo AV, Isles C, Geddes C, Deighan C. Potassium disorders--clinical spectrum and emergency management. Resuscitation 2006; 70: 10-25. [CrossRef] 